\title{
The Fate of Di-(3,5-di-tert.-butyl-4-hydroxyphenyl)methane (Ionox 220) in the Rat
}

\author{
By A. S. WRIGHT, R. S. CROWNE AND D. E. HATHWAY \\ Tunstall Laboratory, 'Shell' Research Ltd., Sittingbourne, Kent
}

(Received 13 September 1965)

\begin{abstract}
1. A large proportion of a single oral dose of [ $\left.{ }^{14} \mathrm{C}\right]$ Ionox 220 to rats is eliminated in 24 days : 89.3-97.4\% of the label is excreted in the faeces (much of this is eliminated in the first 4 days after dosage), $1 \%$ in the urine and less than $0.1 \%$ in the expired gases; $4.06 \%$ of ${ }^{14} \mathrm{C}$ is present in the carcass and viscera after removal of the gut, and most of this is in the fatty tissues. 2. About $87 \%$ of ${ }^{14} \mathrm{C}$ in the faeces is due to unchanged antioxidant, $5 \%$ to the quinone methide, $5 \%$ to the free acid and $3 \%$ to an unidentified polar constituent. Three-fifths of ${ }^{14} \mathrm{C}$ in the urine is due to 3,5-di-tert.-butyl-4-hydroxybenzoic acid and the remainder to the ester glucuronide. In three individual animals, one-half of ${ }^{14} \mathrm{C}$ in the bile is due to the free acid, onequarter to the ester glucuronide and the remainder to unchanged antioxidant, whereas in another all of ${ }^{14} \mathrm{C}$ in the bile is due to Ionox 220 . About $97 \%$ of ${ }^{14} \mathrm{C}$ in the body fat is due to unchanged antioxidant and the remainder to the free acid. 3. Up to $20 \%$ of a single oral dose of Ionox 220 is absorbed in rats: $13-14 \%$ is metabolized. 3,5-Di-tert.-butyl-4-hydroxybenzoic acid accounts for just over $5 \%$ of a dose of Ionox 220, 3,5-di-tert.-butyl-4-hydroxybenzoyl- $\beta$-D-glucopyranosiduronic acid for less than $0.4 \%$, the quinone methide for just over $5 \%$ and an unidentified compound for less than 3\%. 4. The physiological and biochemical implications of ingesting Ionox 220 are discussed.
\end{abstract}

Di-(3,5-di-tert.-butyl -4-hydroxyphenyl)methane (I) (Ionox 220), which is an effective antioxidant in certain lubricating oils, protects raw rubber polymers during drying and is useful in vulcanizates based on natural rubber, polyisoprene and styrenebutadiene rubber. Ionox 220 is also incorporated into plastics, which may be used as food-wrapping materials, and this commercial application makes an understanding of the metabolic fate of Ionox 220 desirable.

Ionox 220 is one of a number of structurallyrelated hindered phenolic antioxidants, of which 2,4,6 - tri - ( $3{ }^{\prime} 5^{\prime}$ - di - tert. - butyl - $4^{\prime}$ - hydroxybenzyl)mesitylene (II) (Ionox 330) is not absorbed from the gastro-intestinal tract (Wright, Crowne \& Hathway, 1965a), whereas 2,6 - di - tert. - butyl - 4 - hydroxymethylphenol (III) (Ionox 100) is quantitatively absorbed and metabolized (Wright, Akintonwa, Crowne \& Hathway, 1965b). Investigation of the alimentary absorption of another hindered phenolic antioxidant, e.g. Ionox 220, with molecular properties intermediate between those of Ionox 100 and Ionox 330, was required to put the behaviour of Ionox 100 and Ionox 330 in vivo into perspective.

\section{MATERIALS}

Ionox 220. This compound, m.p. $155-156^{\circ}$, which was synthesized by base-catalysed condensation of 2,6-di-tert.butylphenol with formaldehyde in tert.-butyl alcohol (Filbey \& Coffield, 1957), ran as a single spot in light petroleum (b.p. $\left.40-60^{\circ}\right)$ or light petroleum-ether $(49: 1, v / v)$ as solvent system by using thin-layer chromatography, and carbon tetrachloride-SbCl 5 as location reagent (Wright et al. $1965 b$ ).

3,5-Di-tert.-butyl-4-hydroxybenzoic acid. This compound, m.p. $210^{\circ}$, was prepared by Cannizzaro reaction of 3,5-ditert.-butyl-4-hydroxybenzaldehyde (Yohe et al. 1956), which was itself obtained by bromine oxidation of B.H.T. (2,6-di-tert.-butyl-p-cresol) (Coppinger \& Campbell, 1953).

3,5 - Di - tert. - butyl -4 - hydroxybenzoyl - $\beta$ - D - glucopyranosiduronic acid. This compound, which was separated from the urine of a rabbit that had been intubated with 3,5-ditert.-butyl-4-hydroxybenzoic acid by the method of Wright et al. (1965b), ran as a single spot in two solvent systems (Table 3) by using paper chromatography, and naphtharesorcinol-trichloroacetic acid as location reagent (Elliott, Parke \& Wiliams, 1959).

$3^{\prime}, 5^{\prime}$ - Di-tert.-butyl-4' - hydroxyphenyl-(2,6-di-tert.-butylp-benzoquinone) methide (the quinone methide). Ionox 220 was oxidized by $\mathrm{PbO}_{2}$ in light petroleum to a stable phenoxy radical (Coppinger, 1957), which was reduced with quinol 
<smiles>CC(C)(C)c1cc(Cc2cc(C(C)(C)C)c(O)c(C(C)(C)C)c2)cc(C(C)(C)C)c1O</smiles>

(I)<smiles>Cc1c(Cc2cc(O)c(O)c(C(C)(C)C)c2)c(C)c(Cc2cc(C(C)(C)C)c(O)c(C(C)(C)C)c2)c(C)c1Cc1cc(C(C)(C)C)c(O)c(C(C)(C)C)c1</smiles>

(II)<smiles>CC(C)(C)c1cc(C=O)cc(C(C)(C)C)c1O</smiles>

(III) in ether to the quinone methide (Coppinger, 1957). Recrystallization of the quinone methide from light petroleum afforded orange-yellow needles, m.p. 157-158 .

We have established that the quinone methide is an intermediate in the oxidation of Ionox 220 to Coppinger's (1957) stable phenoxy radical $(a)$ by following the course of the reaction spectroscopically and (b) by isolating authentic quinone methide from an interrupted reaction. Our absorption spectra for the quinone methide and Coppinger's (1957) stable phenoxy radical were identical with those previously described by Kharasch \& Joshi (1957a).

2,6 - Di - tert. - butyl - p - benzoquinone. This compound crystallized from methanol in orange-yellow crystals, m.p. $68^{\circ}$ (Bickel, Kooyman, la Lau, Roest \& Piet, 1953), and was prepared from 2,6-di-tert.-butylphenol by the method of Chambers (1959).

Bovine liver $\beta$-D-glucuronidase. This enzyme, [1 g., 560000 units (Fishman, Springer \& Brunetti, 1948)] was obtained from the Sigma Chemical Co., St Louis, Mo., U.S.A.

Reagents and solvents. All reagents and solvents were of A.R. grade. Diethyl ether was dried over $\mathrm{Na}$ and redistilled over reduced $\mathrm{Fe}$ immediately before use.

$D i$ - (3,5 - di - tert. - butyl - 4 - hydroxyphenyl $)\left[{ }^{14} \mathrm{C}\right]$ methane ([14 $\mathrm{C}]$ Ionox 220$)$. This compound $(0.905 \mu \mathrm{c} / \mathrm{mg}$.) was synthesized by mixing a solution of potassium tert.-butoxide (10 mg.) in anhydrous tert.-butyl alcohol with a solution of 2,6-di-tert.-butylphenol (494 mg.) and [ $\left.{ }^{14} \mathrm{C}\right]$ paraformaldehyde (30 mg., 381.6 $\mu \mathrm{c}$ ) in tert.-butyl alcohol under $\mathrm{N}_{2}$ at $0^{\circ}$, and by maintaining the reaction mixture at $12^{\circ}$ for $40 \mathrm{~min}$. to yield 2,6-di-tert.-butyl-4[14C]-hydroxymethylphenol, which was treated with the excess of 2,6-di-tert.-butylphenol in the original reaction mixture by raising the temperature and maintaining it at $80^{\circ}$ for a further period of $1 \mathrm{hr}$. The catalyst was subsequently poisoned with $\mathrm{CO}_{2}$ and the solution was neutralized by addition of aq. $10 \%(w / v)$ $\mathrm{NH}_{4} \mathrm{Cl}$. The residue, which was washed with tert.-butyl alcohol and recrystallized from cyclohexane, afforded a $96 \%$ yield of $\left.{ }^{\left[{ }^{14}\right.} \mathrm{C}\right]$ Ionox 220 , m.p. $155-156^{\circ}$. The ${ }^{14} \mathrm{C}$. labelled antioxidant behaved identically with an authentic specimen of unlabelled Ionox 220 on thin-layer plates of Kieselgel G run with light petroleum or light petroleumether $(49: 1, v / v)$; radioautography did not reveal radioactive impurities. The radiochemical purity of the compound exceeded $\mathbf{9 9 . 9} \%$.

\section{METHODS}

Experiments with animals. Adult rats (approx. 3 months old, 200-225g. body wt.) were used (Porton strain maintained as a specific pathogen-free colony in this Laboratory). For the metabolism experiments, the animals $(200 \mathrm{~g}$. body wt.) were kept singly in all-glass metabolism cages, under the conditions described by Wright et al. (1965b). In the preliminary experiment, a solution of $\left[{ }^{14} \mathrm{C}\right]$ Ionox 220 ( $11 \mathrm{mg}$., $0.905 \mu \mathrm{c} / \mathrm{mg}$.) in $2 \mathrm{ml}$. of olive oil was administered to rats by stomach tube. Unrestricted food and water were supplied, the urine and faeces were collected and stored at $-29^{\circ}$, and the exhaled gases were monitored for ${ }^{14} \mathrm{CO}_{2}$. The rats were killed $2,4,6,12,24$ and $48 \mathrm{hr}$. after dosage, when the alimentary canal, feet, head, skin plus hair and tail were removed, and the carcass and remaining viscera were examined for radioactivity. In another experiment, a solution of [ ${ }^{14} \mathrm{C}$ ] Ionox 220 ( $10 \mathrm{mg}$., $0.905 \mu \mathrm{c} / \mathrm{mg}$.) in $2 \mathrm{ml}$. of olive oil was administered by stomach tube to four adult rats of each sex $(200 \mathrm{~g}$. body wt.). Unrestricted food and water were supplied, the urine and faeces were collected daily and stored at $-29^{\circ}$. In this experiment, pairs of animals (one of each sex) were killed 4, 8, 16 and 24 days after dosage. The entire alimentary canal and contents, the skin plus hair, the whole liver and a standard amount of intra-abdominal and subcutaneous fats were dissected from each cadaver, and these organs and tissues together with the carcass and remaining viscera were stored at $-29^{\circ}$.

Biliary fistulae were established in rats (225g. body wt.) that had previously been intubated with a solution of $10 \mathrm{mg}$. of [ ${ }^{14} \mathrm{C}$ ]Ionox $220(0.905 \mu \mathrm{c} / \mathrm{mg}$.) in $2 \mathrm{ml}$. of olive oil. After recovery from the operation, the animals were placed in individual restraining cages, where they had access to unrestricted food and water. Bile was collected during $2 \cdot 0-30 \cdot 5 \mathrm{hr}$. after dosage in $2 \mathrm{ml}$. portions by using an automatic fraction collector. These animals were killed at the end of the experiment.

Extraction of radioactivity from urine, bile, faeces and tissues. Ether extracts of the urines of treated animals were made by continuous extraction in a Schacherl apparatus at pH6.0 and $\mathrm{pH} 1.5-2.0$ successively: $97 \%$ of the ${ }^{14} \mathrm{C}$ was recovered; $95 \%$ of the radioactivity was recovered from bile by similar extraction. A total lipid fraction was prepared from crushed rat faeces by exhaustive extraction 
with acetone (Soxhlet): $95 \%$ of the ${ }^{14} \mathrm{C}$ in faeces was extracted during $72 \mathrm{hr}$. The ${ }^{14} \mathrm{C}$ was extracted from tissues with acetone. Evaporations were carried out in $\mathrm{N}_{2}$ under reduced pressure at below $35^{\circ}$.

Chromatography on a silica-gel column. Hopkin and Williams (100 mesh) silica gel M.F.C. was washed and reactivated, as described by Wright et al. (1965b). Lipidsoluble ${ }^{14} \mathrm{C}$-labelled components in faeces and body fat were separated by adsorption chromatography with solvents of increasing polarity; a typical fractionation is set out in Table 5. Separation of lipids was effected in the dark.

Paper chromatography. Ionox 220 and its metabolites, with the exception of the quinone methide, were separated by descending chromatography on Whatman no. 1 filter paper at $29^{\circ}$, and Table 3 shows the degree of separation that can be achieved by using two solvent systems. All ${ }^{14} \mathrm{C}$-labelled constituents were detected and identified by radioactive scanning with a Nuclear-Chicago Actigraph II, equipped with a gas-flow cell utilizing a helium- $n$-butane $(98 \cdot 5: 1 \cdot 5, \mathrm{v} / \mathrm{v})$ mixture. Radioautographs were also used (Table 5). The antioxidant and its metabolites were also detected and identified on paper with the following location reagents: (1) Gibb's reagent, applied as described by Wright et al. $(1965 b)$; (2) carbon tetrachloride- $\mathrm{SbCl}_{5}$ (Wright et al. 1965a); (3) naphtharesorcinol prepared by the method of Elliott et al. (1959). Paper chromatography was also used for the purification of 3,5-di-tert.-butyl-4-hydroxybenzoyl- $\beta$-D-glucopyranosiduronic acid (for details, see the Materials section), and for the location and identification of glucuronic acid in the enzymic hydrolysate (for details, see the Methods section).

Thin-layer chromatography. Thin-layer chromatography on Kieselgel G (E. Merck A.-G., Darmstadt, Germany) was carried out at $29^{\circ}$ as described by Wright et al. (1965b). The ${ }^{14} \mathrm{C}$-labelled metabolites were detected and identified on thin plates by radioautography, and measured in eluates of the excised spots by liquid-scintillation counting. Thinlayer chromatography was useful for separating Ionox 220 and the quinone methide; light petroleum-ether $(49: 1, \mathrm{v} / \mathrm{v})$ was used as solvent system (Tables 3 and 5). The purity of unlabelled and ${ }^{14} \mathrm{C}$-labelled Ionox 220 was checked by thin-layer chromatography, with light petroleum or light petroleum-ether $(49: 1, v / v)$ as solvent system. Thin-layer chromatography was used for the separation of 2,6-di-tert.butyl-p-benzoquinone from faeces and body fat.

Measurement of radioactivity. A Tri-Carb spectrometer (Packard Instrument Co. Inc., La Grange, Ill., U.S.A.) was used for the measurement of ${ }^{14} \mathrm{C}$ by liquid-scintillation counting. Measurements of radioactivity in urine, faeces, gut and contents, carcass plus viscera, skin plus hair, liver, intra-abdominal and subcutaneous fats, and of the ${ }^{14} \mathrm{CO}_{2}$ in the expired gases, were made by the methods described by Wright et al. (1965b).

Enzymic hydrolysis of the ester glucuronide. 3,5-Di-tert.butyl-4-hydroxybenzoyl- $\beta$-D-glucopyranosiduronic acid $(0.5 \mathrm{mg}$.), separated by paper chromatography from the urine or bile of treated animals, was dissolved in $0.15 \mathrm{M}$ sodium acetate buffer, $\mathrm{pH} 4.2$ ( $1 \mathrm{ml}$.), and incubated with $\beta$-glucuronidase (50 units) at $37^{\circ}$ for $3 \mathrm{hr}$., when the mixture was extracted with ether. 3,5-Di-tert.-butyl-4-hydroxybenzoic acid was detected as a single spot in butan-1-ol$2 \mathrm{~N} \cdot \mathrm{NH}_{3}$ by using paper chromatography, and Gibb's reagent as location reagent (Table 4). Free glucuronic acid was detected with naphtharesorcinol (Tollens, 1908, 1910),
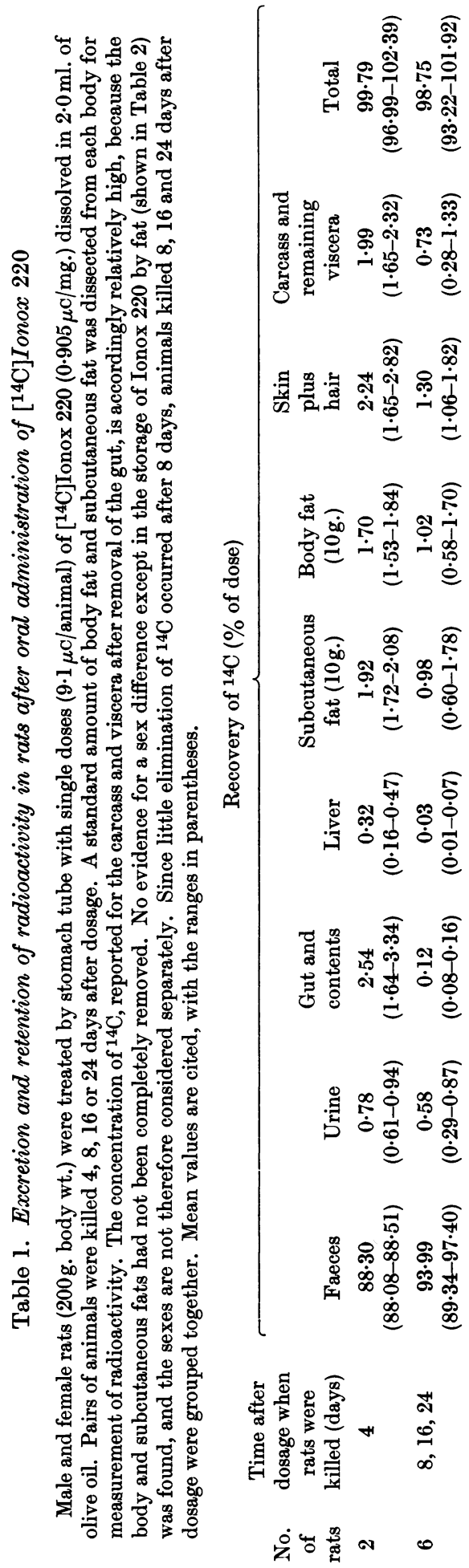
and was identified on paper chromatograms of the concentrated aqueous phase run in butan-1-ol-acetic acidwater $(4: 1: 1$, by vol.) with naphtharesorcinol (Elliott et al. 1959 ) and $p$-anisidine hydrochloride (Hough, Jones \& Wadman, 1950) as location reagents.

Unlabelled metabolites. Separation by thin-layer chromatography of individual ${ }^{14} \mathrm{C}$-labelled metabolites in the various fractions from column chromatography of faecal total lipid revealed a dull-yellow zone of unlabelled 2,6-ditert.-butyl- $p$-benzoquinone, identified by its location (Table 3) and absorption spectrum in $n$-hexane $\left(\lambda_{\max }\right.$. $254 \mathrm{~m} \mu$ ).

\section{RESULTS}

Excretion and retention of radioactivity in rats dosed with $\left[{ }^{14} \mathrm{C}\right]$ Ionox 220 . Four adult rats of each sex were treated orally with $\left[{ }^{14} \mathrm{C}\right]$ Ionox 220 , and pairs of animals were killed 4, 8, 16 and 24 days after dosage. Less than $0 \cdot 1 \%$ of the dose appeared in the expired gases during $48 \mathrm{hr}$. The investigation of excretion and retention of radioactivity in these orally treated animals is summarized in Table 1. Less than $1 \%$ of the original label was excreted in the urine and $89 \cdot 4-97 \cdot 4 \%$ in the faeces during 24 days, where these values include the contents of the gut on the twenty-fourth day. Initial elimination in the faeces, however, was comparatively rapid, $\mathbf{8 6 . 5 8 - 9 4 . 6 2 \% ~ ( 8 ) ~ i n ~} 4$ days. Rats do not show a sex difference in this pattern of elimination of Ionox 220 and its metabolites, and the sexes are not therefore considered separately. Since there was little elimination of ${ }^{14} \mathrm{C}$ after 8 days, animals killed 8,16 and 24 days after dosage were considered as one group.

That considerable alimentary absorption occurred in rats dosed orally with $\left[{ }^{14} \mathrm{C}\right]$ Ionox 220 is shown (a) by the retention of radioactivity in the body tissues and $(b)$ by the secretion of ${ }^{14} \mathrm{C}$ into the bile.

The carcass and viscera remaining after removal of the gut of the rats, killed 4 days after dosage, contained $8.2 \%$ of ${ }^{14} \mathrm{C}$, and this value fell to $4.0 \%$ in animals killed 24 days after dosage. After an oral dose of $\left[{ }^{14} \mathrm{C}\right]$ Ionox 220 , more ${ }^{14} \mathrm{C}$ is stored in the fatty tissues, including the subcutaneous fats, body fats and pelts, than in the organs. After 24 days, the concentrations of ${ }^{14} \mathrm{C}$ in the liver of male and female rats had fallen to less than 0.1 and 0.1 p.p.m. respectively, whereas the concentrations of ${ }^{14} \mathrm{C}$ in the subcutaneous fat, body fat and skin plus hair of male rats after 8 days had fallen to one-half or less of the values at 4 days, and they then remained stationary during 8-24 days; there is even greater retention of ${ }^{14} \mathrm{C}$ in the fatty tissues of female rats than of males (Table 2).

Representative results for the collection of bile from two male and two female rats dosed with $\left[{ }^{14} \mathrm{C}\right]$ Ionox 220 are summarized in Table 3. Maximum concentration of ${ }^{14} \mathrm{C}$ in the bile of these animals occurred during 4-12 hr. after dosage. After $18 \mathrm{hr}$., the concentration of ${ }^{14} \mathrm{C}$ in the bile of each animal fell very slowly. These observations suggest that a low degree of alimentary absorption had taken place, and that diffusion of ${ }^{14} \mathrm{C}$-labelled products from plasma to bile was slow. At least $15 \%$ of the ${ }^{14} \mathrm{C}$ excreted in the faeces during 24 days originated in the bile, since $11 \%$ of ${ }^{14} \mathrm{C}$ was secreted in the $30 \mathrm{hr}$. bile (Table 3 ), and since $4 \cdot 1 \%$ of ${ }^{14} \mathrm{C}$ was eliminated from the organs and tissues during 4-24 days (Table 1). When allowance is made for retention of ${ }^{14} \mathrm{C} 24$ days after dosage, it follows that about $20 \%$ of a single dose of $\left[{ }^{14} \mathrm{C}\right]$ Ionox 220 was absorbed in rats.

Separation and estimation of individual radioactive compounds in the urine, faeces, body fat and bile of rats dosed with $\left[{ }^{14} \mathrm{C}\right]$ Ionox 220 . Radioactivity was recovered quantitatively from the urine of rats, which had been treated with $\left[{ }^{14} \mathrm{C}\right]$ Ionox 220 , by successive ether extraction at $\mathrm{pH} 6 \cdot 0$ and $\mathrm{pH} 1 \cdot 5-2 \cdot 0$. The ether extract prepared at $\mathrm{pH} 6.0$ from the 24-day urine contained one-and-a-half times the amount of ${ }^{14} \mathrm{C}$ as that prepared at $\mathrm{pH} 1 \cdot 5-2 \cdot 0$. Paper

Table 2. Tissue concentrations of radioactivity in rats after oral administration of $\left[{ }^{14} \mathrm{C}\right]$ Ionox 220

Male and female animals were treated with $\left[{ }^{14} \mathrm{C}\right]$ Ionox 220 as described in Table 1.

\begin{tabular}{|c|c|c|c|c|c|c|}
\hline \multirow[b]{2}{*}{$\begin{array}{l}\text { Rat } \\
\text { no. }\end{array}$} & \multirow[b]{2}{*}{ Sex } & \multirow{2}{*}{$\begin{array}{l}\text { Time after } \\
\text { dosage when } \\
\text { rats were } \\
\text { killed (days) }\end{array}$} & \multicolumn{4}{|c|}{$\begin{array}{c}\text { Concn. of }{ }^{14} \mathrm{C} \\
\text { (expressed in terms of p.p.m. of Ionox 220) }\end{array}$} \\
\hline & & & Liver & $\begin{array}{l}\text { Subcutaneous } \\
\text { fat }\end{array}$ & $\begin{array}{l}\text { Body } \\
\text { fat }\end{array}$ & $\begin{array}{l}\text { Skin } \\
\text { plus hair }\end{array}$ \\
\hline 1 & t & 4 & $4 \cdot 0$ & 21 & 18 & 4 \\
\hline 3 & $\sigma$ & 8 & 0.5 & 8 & 8 & 2 \\
\hline 5 & 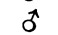 & 16 & $0 \cdot 1$ & 6 & 6 & 2 \\
\hline 7 & 0 & 24 & $<0.1$ & 7 & 6 & 2 \\
\hline 2 & 우 & 4 & $2 \cdot 0$ & 17 & 15 & 3 \\
\hline 4 & q & 8 & $0 \cdot 6$ & 13 & 12 & 3 \\
\hline 6 & 우 & 16 & $0 \cdot 3$ & 18 & 17 & 3 \\
\hline 8 & 우 & 24 & 0.1 & 10 & 9 & 2 \\
\hline
\end{tabular}


Table 3. Time-course for the secretion of ${ }^{14} \mathrm{C}$ into the bile of rats after oral treatment with $\left[{ }^{14} \mathrm{C}\right]$ Ionox 220

Single doses (10 mg./animal) of [ $\left.{ }^{14} \mathrm{C}\right]$ Ionox $220(0.905 \mu \mathrm{C} /$ $\mathrm{mg}$.) dissolved in $2.0 \mathrm{ml}$. of olive oil were administered orally to two male and two female rats $(225 \mathrm{~g}$. body wt.) at zero time, and biliary fistulae were established at a short time thereafter. The post-operative animals were provided with unrestricted water and standard pellet diet, and bile was collected during $2 \cdot 0-30.5 \mathrm{hr}$. after dosage in $2 \mathrm{ml}$. portions by using an automatic fraction collector. No sex difference was apparent, and the single set of results given was representative of both sexes.

\section{Bile}

\begin{tabular}{cccc}
$\begin{array}{c}\text { secreted } \\
\text { (ml.) }\end{array}$ & $\begin{array}{c}\text { Time } \\
\text { (hr.) }\end{array}$ & $\begin{array}{c}\text { Concn. of }{ }^{14} \mathrm{C} \text { in bile } \\
\text { (\% of dose/ml.) }\end{array}$ & $\begin{array}{c}\text { Amount of }{ }^{14} \mathrm{C} \\
\text { (\% of dose) }\end{array}$ \\
2 & $4 \cdot 0$ & $0 \cdot 12$ & $0 \cdot 24$ \\
4 & & $0 \cdot 41$ & $1 \cdot 05$ \\
6 & $8 \cdot 0$ & $0 \cdot 77$ & $2 \cdot 60$ \\
8 & & $0 \cdot 81$ & $4 \cdot 22$ \\
10 & & $0 \cdot 60$ & $5 \cdot 43$ \\
12 & & $0 \cdot 52$ & $6 \cdot 47$ \\
14 & & $0 \cdot 38$ & $7 \cdot 22$ \\
16 & & $0 \cdot 33$ & $7 \cdot 88$ \\
18 & & $0 \cdot 23$ & $8 \cdot 44$ \\
20 & 22.5 & $0 \cdot 27$ & $8 \cdot 98$ \\
22 & & $0 \cdot 23$ & $9 \cdot 44$ \\
24 & 26.5 & $0 \cdot 25$ & $9 \cdot 94$ \\
26 & & $0 \cdot 23$ & $10 \cdot 41$ \\
28 & & $0 \cdot 25$ & $10 \cdot 70$ \\
30 & 30.5 & $0 \cdot 25$ & $11 \cdot 00$ \\
& & & \\
\hline
\end{tabular}

chromatograms of representative samples of the ether extracts from each of the 4-day urines from each of the eight rats were run in two solvent systems and scanned for radioactivity. Ionox 220 was not present among the metabolites in the urine. The single peak of ${ }^{14} \mathrm{C}$ in the extracts prepared at pH 6. 0 corresponded to ${ }^{14} \mathrm{C}$-labelled 3,5 -di-tert.butyl-4-hydroxybenzoic acid, which was identified by isotope-dilution methods, and the single peak of ${ }^{14} \mathrm{C}$ in extracts prepared at $\mathrm{pH} 1 \cdot 5-2 \cdot 0$ corresponded to 3,5-di-tert.-butyl-4-hydroxybenzoyl- $\beta$-D-glucopyranosiduronic acid, which was also located by Gibb's reagent and naphtharesorcinol on paper chromatograms (Table 4) of ether extracts similarly prepared from the urine of rabbits dosed with 3,5-di-tert.-butyl-4-hydroxybenzoic acid. The constitution of this ester glucuronide was confirmed by enzymic hydrolysis with $\beta$-glucuronidase.

Unchanged $\left[{ }^{14} \mathrm{C}\right]$ Ionox 220 , which accounts for $87 \%$ of the ${ }^{14} \mathrm{C}$ in solvent extracts of the faeces of treated rats (Table 5), was separated from the total lipid fraction of rat faeces by column chromatography on silica gel (Table 6). A small proportion of contaminating ${ }^{14} \mathrm{C}$-labelled quinone methide was separated from the fraction containing $\left[{ }^{14} \mathrm{C}\right]$ Ionox 220 by thin-layer chromatography (Table 4) and esțimated by radioacțive scanning (Table 5). A

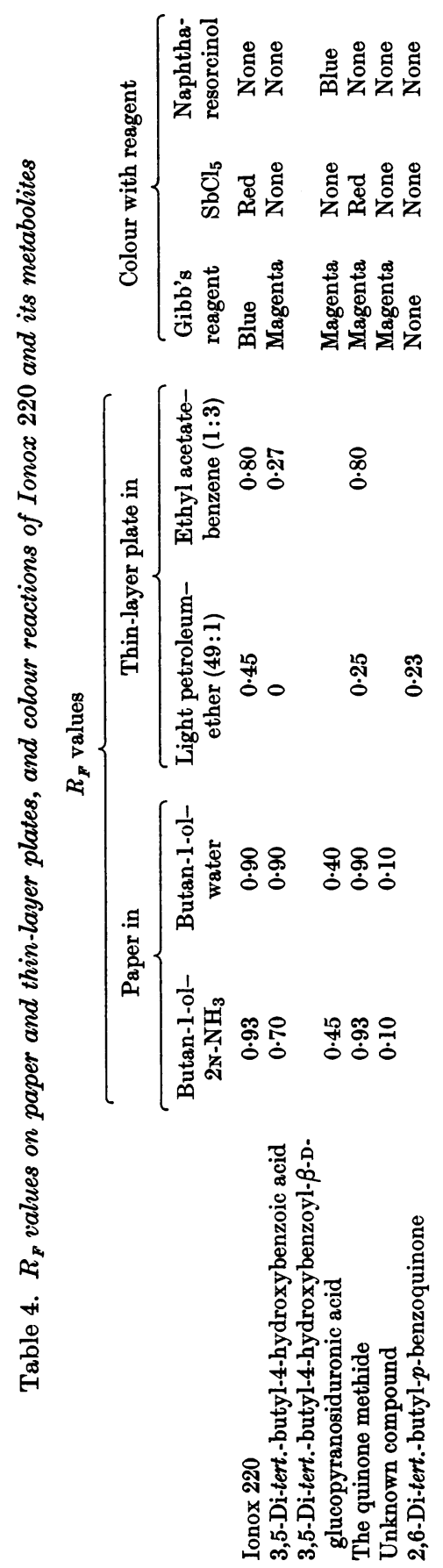


middle fraction from the column contained a small amount of ${ }^{14} \mathrm{C}$-labelled 3,5-di-tert.-butyl-4-hydroxybenzoic acid (Table 6). When the late fractions, which contained a small amount of a slow-moving radioactive component, were chromatographed on paper, radioautography revealed traces of 3,5-ditert.-butyl-4-hydroxybenzoic acid and of an unidentified component with $R_{\boldsymbol{F}} \mathbf{0} \cdot 1$ (Tables 4 and 6). Unlabelled 2,6-di-tert.-butyl-p-benzoquinone was also isolated from a middle fraction of faecal lipids.

Chromatography, on similar silica-gel columns of solvent extracts of the body fat of rats dosed with [ $\left.{ }^{14} \mathrm{C}\right]$ Ionox 220 , showed that $97 \%$ of the ${ }^{14} \mathrm{C}$ was present as unchanged $\left[{ }^{14} \mathrm{C}\right]$ Ionox 220 , together with a small amount of ${ }^{14} \mathrm{C}$-labelled 3,5-di-tert.-butyl-4- hydroxybenzoic acid and traces of ${ }^{14} \mathrm{C}$-labelled quinone methide and an unidentified ${ }^{14} \mathrm{C}$-labelled compound (Table 5).

A biliary fistula was established in each of four rats that had previously been dosed with [14C]Ionox 220 , bile was collected during $2-30.5 \mathrm{hr}$. after dosage, and radioactivity was recovered quantitatively by ether extraction at $\mathrm{pH} 1 \cdot 5-2 \cdot 0$. Radioactive components in this solvent extract were separated by paper chromatography (Table 4) and estimated by radioactive scanning. There was evidence of interaction between ${ }^{14} \mathrm{C}$-labelled metabolites and component(s) of normal bile, since the bad resolution on the initial chromatograms was greatly improved by rechromatography on paper of selected ${ }^{14} \mathrm{C}$-labelled

Table 5. Relative proportions of unchanged antioxidant and of the individual metabolites present in body fluids, faeces and body fat of rats treated orally with $\left[{ }^{14} \mathrm{C}\right]$ Ionox 220

The urine, faeces and body fat of four pairs of treated rats were pooled according to sex. Since the relative proportions of Ionox 220 metabolites found in the duplicate samples were identical, the results given are considered to be representative of rats dosed with [14 C]Ionox 220 irrespective of sex. For bile, mean values are given with the ranges in parentheses.

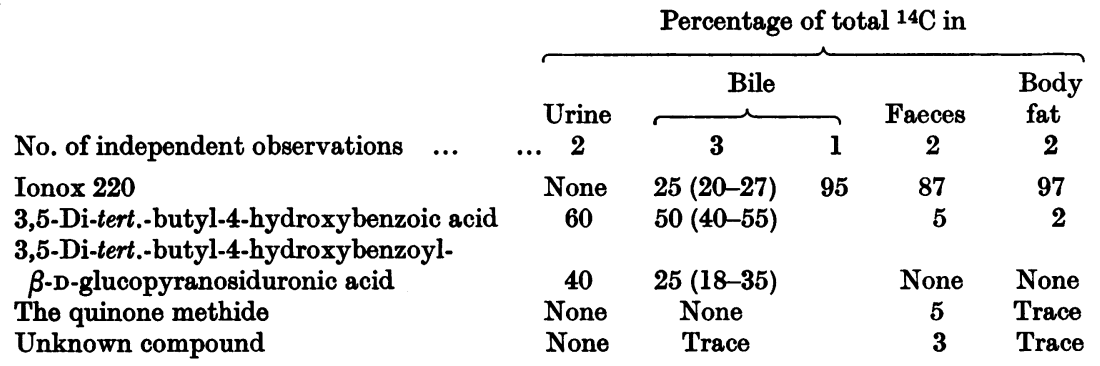

Table 6. Separation of $\left[{ }^{14} \mathrm{C}\right]$ Ionox 220 and its ${ }^{14} \mathrm{C}$-labelled metabolites from the acetone-soluble fraction of rat faeces by adsorption chromatography on silica gel

A portion of the total lipid fraction from the faeces of rats $(200 \mathrm{~g}$. body wt.) that had been treated orally with $9 \cdot 1 \mu \mathrm{C}$ of [ $\left.{ }^{14} \mathrm{C}\right]$ Ionox $220(0.905 \mu \mathrm{C} / \mathrm{mg}$.)/animal was chromatographed on a silica-gel column $(30 \mathrm{~mm} . \operatorname{diam} . \times 25 \mathrm{~cm}$. long). Recovery was quantitative.

Fraction no. (500 ml.)

1 2 3
Eluent

Light petroleum (b.p. $40-60^{\circ}$ ) $2 \%$ Ether in light petroleum $2 \%$ Ether in light petroleum

$4 \quad 4 \%$ Ether in light petroleum

$5 \quad 10 \%$ Ether in light petroleum ? $620 \%$ Ether in light petroleum $7 \quad 50 \%$ Ether in light petroleum $8 \quad$ Ether

Recovery of radioactive constituents

No radioactivity

No radioactivity

$91.8 \%$ of ${ }^{14} \mathrm{C}$; Ionox 220 was separated by thin-layer chromatography (for details see Table 3), cryst. from $n$-hexane in rosettes of needles, m.p. and mixed m.p. $155^{\circ}$; the ${ }^{14} \mathrm{C}$-labelled quinone methide was also separated by thin-layer chromatography $0.2 \%$ of ${ }^{14} \mathrm{C}$

$5.0 \%$ of ${ }^{14} \mathrm{C}$; 3,5-di-tert.-butyl-4-hydroxybenzoic acid, m.p. $210^{\circ}$, was identified by isotope-dilution methods No radioactivity $3.0 \%$ of ${ }^{14} \mathrm{C}$; radioautographs of paper chromatograms showed ${ }^{14} \mathrm{C}$-labelled 3,5-di-tert.-butyl-4-hydroxybenzoic acid and one slow-moving polar ${ }^{14} \mathrm{C}$-labelled metabolite 


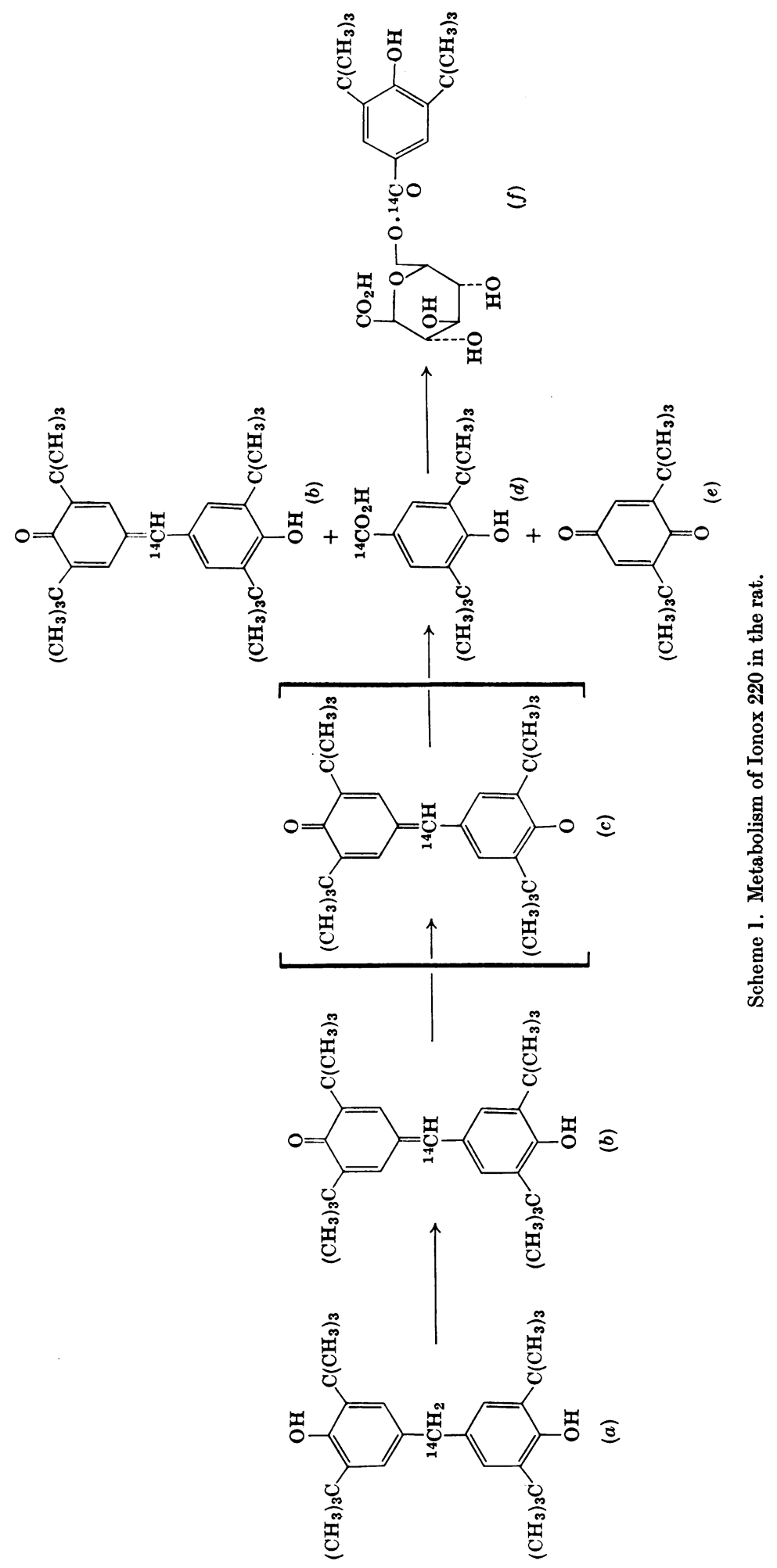


zones. In three of these rats ${ }^{14} \mathrm{C}$-labelled 3,5-ditert.-butyl-4-hydroxybenzoic acid accounted for one-half of the ${ }^{14} \mathrm{C}$ in the bile of biliary-fistula rats, one-quarter was due to the ${ }^{14} \mathrm{C}$-labelled ester glucuronide and one-quarter to unchanged $\left[{ }^{14} \mathrm{C}\right]$ Ionox 220 (Table 5). A trace of the unidentified ${ }^{14} \mathrm{C}$-labelled compound was also present. In another biliary-fistula rat, however, $95 \%$ of the ${ }^{14} \mathrm{C}$ in the bile was due to unchanged $\left[{ }^{14} \mathrm{C}\right]$ Ionox 220 (Table 5). Ester glucuronide secreted into bile was unconjugated by the intestinal flora, and free 3,5-di-tert.butyl-4-hydroxybenzoic acid was excreted in the faeces.

The metabolism of Ionox 220 in vivo is closely related to its antioxidant action in vitro. Thus in the present work we have shown that oxidation in vitro of Ionox 220 (a) (Scheme 1) to Coppinger's (1957) stable phenoxy radical (c) proceeds via $3^{\prime}, 5^{\prime}$-di-tert. -butyl-4'-hydroxyphenyl-(2,6-di-tert. butyl-p-benzoquinone) methide (b) (the quinone methide). Further, Kharasch \& Joshi (1957b) have shown that oxidation of 2 mol.prop. of Coppinger's (1957) stable phenoxy radical (c) by molecular oxygen in alkali affords 1 mol.prop. of each of the products: the quinone methide $(b), 3,5$-di-tert.butyl - 4 - hydroxybenzaldehyde and 2,6 - di - tert. butyl- $p$-benzoquinone $(e)$. Since the metabolism of Ionox 220 in vivo affords the quinone methide (b), 3,5-di-tert.-butyl-4-hydroxybenzoic acid $(d)$, the ester glucuronide $(f)$ and 2,6-di-tert.-butyl-p-benzoquinone $(e)$, the preferred scheme for the metabolism of Ionox 220 in vivo is that shown in Scheme 1. Coppinger's (1957) stable phenoxy radical (c) has not, however, been isolated in our metabolism study. It may be relevant that, since compounds $(b)-(e)$ can also be produced by mild oxidations in vitro, their formation in vivo need not necessarily be enzymic and may result from antioxidant action in the faeces and body fats. However, conjugation of compound $(d)$ to the ester glucuronide $(f)$ is undoubtedly an enzymic step.

\section{DISCUSSION}

One-fifth of a single dose of Ionox 220 was absorbed in rats, and not all of the proportion of the dose that had been absorbed was metabolized, since some unchanged antioxidant was concentrated in the fatty tissues in vivo and secreted unchanged into the bile of rats with biliary fistulae (Table 5). Among the metabolic products of Ionox 220 in the rat 3,5-di-tert. -butyl-4-hydroxybenzoic acid accounts for just over $5 \%$ of dose, 3,5-di-tert.-butyl-4hydroxybenzoyl- $\beta$-D-glucopyranosiduronic acid for up to $0.4 \%$ of dose, the quinone methide for just over $5 \%$ of dose and the unidentified compound for up to $3 \%$ of dose. Thus $13-14 \%$ of a single oral dose was metabolized.
The physiological and biochemical implications of ingesting a foreign compound, like Ionox 220, are of interest.

The rate of metabolism of foreign compounds is lowered by factors that diminish the effective concentration of foreign compounds at the active sites of the liver microsomal drug-metabolizing enzymes. Ionox 220 seems to have been precipitated in the gastro-intestinal tract, and dissolution of the solid state takes place slowly, with the result that its rate of metabolism by liver microsomal enzymes is limited by the rate of alimentary absorption and concentration in portal blood. The effective concentration of Ionox 220 in systemic circulation is lowered by localization in the fatty tissues, which maintain for a long period of time a low plasma concentration of antioxidant that is slowly metabolized and excreted.

No unchanged Ionox 220 is excreted by the kidneys. Liver microsomal enzymes help to terminate the life of lipid-soluble foreign compounds in the body by transforming them into less lipid-soluble metabolites. Ionox 220 is oxidized to 3,5-di-tert. butyl-4-hydroxybenzoic acid, which is converted into the ester glucuronide, and such conjugates become enmeshed in special tubular mechanisms that are utilized for the rapid clearance of foreign compounds from plasma.

Bigger amounts of 3,5-di-tert.-butyl-4-hydroxybenzoic acid and the ester glucuronide than those excreted by the kidneys were secreted into bile, and diffusion from blood probably accounts for the excretory function of liver. Considerable quantities of unchanged Ionox 220 were also secreted into bile, and in one treated animal Ionox 220 was the only foreign compound present in the bile. These substances were not massively secreted into bile, and parameters relating to the mechanisms governing their appearance in bile are incompletely understood (Brauer, 1959; Combes, 1964 ; Cook, Lawler, Calvin \& Green, 1952). Biliary secretion of Ionox 220, which is not ionized in bile, is probably similar to that of other un-ionized compounds, such as the xanthophylls, cholesterol (Desai, Glover \& Joo, 1965) and neutral steroid-hormone metabolites (Taylor, 1965).

The distribution and retention properties of Ionox 220 are similar to those of vitamin $\mathrm{E}$, and use of a lipid-soluble antioxidant that is absorbed, which would reduce the expenditure of stored vitamin $A$, would afford a means of investigating the role of vitamin $\mathrm{E}$ in vivo. Ionox 220 and vitamin $\mathrm{E}$ are converted in vivo into substituted $p$-benzoquinones.

Finally, the metabolic pathway of Ionox 220 differs from those of other diphenylmethanes that have been investigated. Thus $p$-bromodiphenylmethane is not oxidized in vivo (Klingenberg, 1891; 
Williams, 1959), and in the dog and rabbit unsubstituted diphenylmethane is hydroxylated to give 4-hydroxydiphenylmethane, which is excreted largely in the unconjugated form (Stroud, 1940).

\section{REFERENCES}

Bickel, A. F., Kooyman, E. C., la Lau, C., Roest, W. \& Piet, P. (1953). J. chem. Soc. p. 3211.

Brauer, R. W. (1959). J. Amer. med. Ass. 169, 1462.

Chambers, R. D. (1959). J. chem. Soc. p. 1804.

Combes, B. (1964). In The Liver, vol. 2, p. 5. Ed. by Rouiller, C. New York: Academic Press, Inc.

Cook, D. L., Lawler, C. A., Calvin, L. D. \& Green, D. M. (1952). Amer. J. Physiol. 171, 62.

Coppinger, G. M. (1957). J. Amer. chem. Soc. 79, 501.

Coppinger, G. M. \& Campbell, T. W. (1953). J. Amer. chem. Soc. 75, 734.

Desai, J. C., Glover, J. \& Joo, C. N. (1965). In The Biliary System, p. 145. Ed. by Taylor, W. Oxford: Blackwell Scientific Publications.

Elliott, T. H., Parke, D. V. \& Williams, R. T. (1959). Biochem. J. 72, 193.
Filbey, A. H. \& Coffield, T. H. (1957). U.S. Patent 2807653 (to Ethyl Corp.).

Fishman, W. H., Springer, B. \& Brunetti, R. (1948). J. biol. Chem. 173, 449.

Hough, L., Jones, J. K. N. \& Wadman, H. (1950). J. chem. Soc. p. 1702.

Klingenberg, K. (1891). Jber. Fortschr. Tierchem. $21,57$.

Kharasch, M. S. \& Joshi, B. S. (1957a). J. org. Chem. 22, 1435.

Kharasch, M. S. \& Joshi, B. S. (1957b). J. org. Chem. 22, 1439.

Stroud, S. W. (1940). J. Endocrin. 2, 55.

Taylor, W. (1965). In The Biliary System, p. 339. Ed. by Taylor, W. Oxford: Blackwell Scientific Publications.

Tollens, C. (1908). Hoppe-Seyl. Z. 56, 115.

Tollens, C. (1910). Hoppe Seyl. Z. 67, 138.

Williams, R. T. (1959). Detoxication Mechanisms, 2nd ed., p. 226. London: Chapman and Hall Ltd.

Wright, A. S., Akintonwa, D. A. A., Crowne, R. S. \& Hathway, D. E. (1965b). Biochem. J. 97, 303.

Wright, A. S., Crowne, R. S. \& Hathway, D. E. (1965a). Biochem. J. 95, 98.

Yohe, G. R., Dunbar, J. E., Pedrotti, R. L., Scheidt, F. M., Lee, F. G. H. \& Smith, E. C. (1956). J. org. Chem. 21, 1289. 